удК 792.01+792.072.2(477)

\title{
ВИТОКИ МИСТЕЦТВА РЕЖИСУРИ. ІЗ ПРИЗАБУТИХ РОБІТ УКРАЇНСЬКИХ ТЕАТРОЗНАВЦІВ
}

\section{Олександр Чепалов}

доктор мистецтвознавства, професор; e-mail: chepalovst@gmail.com; ORCID: 0000-0002-2033-357X

Київський національний університет культури і мистецтв, Київ, Україна

\begin{abstract}
Анотація
Режисура як творча професія та проблема створення авторської театральної вистави залишається вже понад століття в центрі обговорення театрознавців, культурологів і фахівців інших галузей дотичних до сценічного мистецтва. Метою дослідження є включення в коло обговорюваних проблем сучасного театру призабутих нині робіт мистецтвознавчого профілю, що були характерними для ключових моментів історії України: ідейно-політичного самовизначення після 1917 р. (М. Вороний, Г. Гаєвський) та повернення до суспільної пам'яті творчих здобутків видатного українського режисера Леся Курбаса (Н. Кузякіна, остання четверть XX ст.). Методи дослідження (насамперед історичний) обумовлені суттєвими часовими проміжками, до яких ми ретроспективно повертаємося з огляду на значущість тієї чи іншої мистецької події, її політичну заангажованість тощо. Іншим домінантним методом є порівняльний, тобто такий, що демонструє схожість або відмінність художніх прийомів театральної вистави у зв'язку з певною суспільнополітичною настановою чи ідеологічними вимогами. Порівняльний метод уможливлює аналіз ознак художнього явища з метою їхньої класифікації та типологічного структурування. Наукова новизна роботи полягає в тому, що звернення до призабутих естетичних концепцій минулого (Г. Гаєвський, М. Вороний) дало змогу по-новому подивитися на усталені уявлення минулих часів і відповідно надати їм сучасного наукового трактування. Висновки дослідження стосуються насамперед місця та ролі Леся Курбаса в різноманітних проявах європейської режисерської теорії та практики XX ст., що й досі недостатньо оцінюються поза межами української театральної культури.
\end{abstract}

Ключові слова: режисура; українське режисерське мистецтво; театрознавчі аспекти режисури; Н. Кузякіна; театр корифеїв; система «образного перетворення» Леся Курбаса

\section{Постановка проблеми}

«Найзаплутаніші та найбільш спірні ситуації сучасного театру незмінно пов'язані з персоною режисера» (Хваленская, ред., 1976, с.14). Так писав у статті, вміщеній у збірці «Біля витоків режисури» (1976), один з найбільш авторитетних теоретиків цієї галузі С. Владимиров. I хоча відтоді минуло більше 40 років, режисура залишається одним з найбільш загадкових феноменів у галузі мистецтва. Тож актуальною $є$ теза дослідника, що усі складнощі сучасного театру неначе народилися разом з режисурою. Історичний розгляд режисури припускає аналіз виникнення й розвитку цієї особливої стильової форми в її закономірності та протиріччях, загальних і конкретних (Хваленская, ред., 1976, с.15). Це ж стосується 
креативної української режисури, представленої в історії вітчизняного театру XX cт. насамперед іменем Леся Курбаса, творчість якого не завжди відповідно сприймалася в різні історичні епохи.

\section{Аналіз останніх досліджень та публікацій}

На жаль, фундаментальні дослідження режисерської професії, у тому числі й на українському ґрунті, залишилися в минулому. 3 таких можемо виокремити дуже змістовну розвідку Ю. Станішевського «Шляхи і проблеми розвитку національного режисерського мистецтва в контексті історії українського драматичного театру» (2004), книгу Д. Чайковського «Шляхи розвитку режисури як професії» (2013) та дисертацію, захищену на початку XXI ст., «Сучасна режисерська діяльність як складова частина культуротворчого процесу» Л. Голубцової (2001). Наявність загальних досліджень українського театрального мистецтва у вигляді нарисів, збірок і монографій суттєво не змінює положення, бо режисуру, що не виходить на рівень культурно-історичних концепцій, у них досліджено поміж інших чинників театрального процесу. Роботи зарубіжних дослідників, зокрема французьких, доводять, що в Європі спостерігають чималу зацікавленість у поглибленні підвалин режисури. Так, Б. Пікон-Валлен, французька дослідниця, професор славістики, учасниця Міжнародної конференції «Лесь Курбас і світовий театральний контекст» (Київ, 2012 р.), обрала темою своєї наукової розвідки питання проторежисури, тобто ії ще остаточно невизначених ознак. Ії співвітчизницю - Ногрет Катрін - зацікавив перший трактат про режисуру в Франції Луї Бек де Фук'єра. В епоху технологічного, а не суто творчого способу побудови вистави це набуває принципового значення. Питаннями української проторежисури та теоретичними роботами в цій галузі науковці та практики майже не цікавляться. 3 історичного досвіду українського театрознавства відомо, що пріоритет подібних досліджень мала ще сорок років тому Н. Кузякіна (1928-1994).

Мета статті полягає у сутнісному перегляді призабутих нині робіт мистецтвознавчого профілю, що були характерними для ключових моментів історії України: ідейно-політичного самовизначення після 1917 р. (Вороний, 1913; Гаєвський, 1930), повернення до суспільної пам'яті творчих здобутків видатного українського режисера Леся Курбаса (Кузякина, 1984) та включення їх у коло найбільш обговорюваних проблем сучасного театру.

\section{Виклад основного матеріалу дослідження}

Невипадково, що магістральні питання виникнення режисури як професії (переважно в Росії, а також у деяких західноєвропейських країнах) були розглянуті в згаданій збірці «Біля витоків режисури» саме представниками знаної СанктПетербурзької театрознавчої школи. Проте під час підготовки цього видання в Ленінградському державному інституті театру, музики та кінематографії вже працювала як викладач і науковець українського походження Н. Кузякіна, якій не знайшлося місця в рідному науковому середовищі. Вичавленій з нього не стільки 
Вісник Київського національного університету культури і мистецтв.

Серія: Сценічне мистецтво

3-за особливостей непокірного характеру, скільки з небажаної в той час тематики власних наукових розробок (Лесь Курбас, М. Куліш, І. Кочерга), Н. Кузякіній довелось шукати притулку в Росії, де в згаданому виші працював знаний україніст, людина прогресивних поглядів і великого педагогічного хисту В. Сахновський-Панкєєв, багатогранно обдарований киянин А. Гозенпуд, який свого часу був зацькований радянськими партійними чиновниками як «безрідний космополіт», та ін.

«Творчість героїв Наталі Борисівни завжди мислилася в складному процесі їхнього національного й суспільного самоусвідомлення й самоствердження, поставала як шлях співбуття, співдії і протидії усталеному існуючому порядкові, обставинам історичної доби, системі, - написала пізніше львів'янка І. Волицька, студентка та згодом аспірантка Кузякіної у ЛГІТМіК. - Науковий інтерес дослідниці спрямовувався передусім на долі митців, які в умовах ідеологічного пресингу, політичних репресій зуміли вистояти й не зламатись, знайти сили на духовний моральний спротив державній машині» (Волицька, 2008, с.33).

Автору цих рядків теж довелося бути студентом Н. Кузякіної та навіть здавати їй залік з дисципліни «Історія театру народів СРСР». Крім цілком зрозумілого наголосу на здобутках українського театрального мистецтва, Н. Кузякіна заохочувала студентів до вивчення грузинського театру та досягнень митців прибалтійських республік (Естонії, Латвії, Литви), що досить часто показували свої вистави в Ленінграді.

Проте своїм першочерговим завданням, як можна побачити з її наукових уподобань, Н. Кузякіна вважала популяризацію доробку Леся Курбаса, ім'я якого повільно, але цілеспрямовано почало повертатися до України. I частково до Росії - СРСР, водночас з ім'ям реабілітованого В. Мейєрхольда. У посібнику «Становлення української радянської режисури» (1984) дослідниця писала, що на той час «серед російськомовних статей про Курбаса й театр 1920-х років можна виокремити лише роботи Н. Корнієнко (1968) та М. Бажана (1983)» (Кузякина, 1984, c. 12). Цього у масштабах значущості доробку Леся Курбаса було замало, і Н. Кузякіна почала залучати до кола прихильників улюбленого українського театру своїх студентів, які приїхали до Ленінграда з різних міст СРСР, отже, випустила посібник, що став важливою науково-дослідною розвідкою та інформаційним джерелом, актуальним до наших часів.

Навчальний посібник Н. Кузякіної, присвячений проблемам формування української радянської режисури 1920-х рр., рецензував один із провідних українських театрознавців, доктор мистецтвознавства В. Айзенштадт та знаменитий «березілець», заслужений артист УРСР Р. Черкашин. А надзавданням цього видання була гостра полеміка авторки з необ'єктивністю та офіціозністю поглядів М. Йосипенка на творчість Леся Курбаса, окреслених у відповідних розділах з історії українського театру (Рудницький, ред., 1966; Строева, ред., 1967).

Вочевидь полеміка сприяла зміні позицій офіційних радянських інстанцій, бо вже в 1987 р., тобто через три роки після виходу посібника Н. Кузякіної, у Москві було надруковано збірку статей та спогадів про Леся Курбаса й частину його літературної спадщини з передмовою дослідниці. Але повернемося до посібника 1984 р. У ньому авторка насамперед зосередила увагу на проблемах 
становлення українського театру початку XX ст. 3 російським та західним театром його феномен поєднували як загальні, так і специфічні ознаки. «якщо раніше в режисерові бачили організатора, а часто й антрепренера, хазяїна трупи, то на порозі XX ст. функції режисера зміцнюються, стають більш творчими, він виступає творцем вистави як єдиного художнього цілого. Потіснивши актора - єдиновладного хазяїна сцени, режисер і частково художник узяли на себе відповідальність за загальне звучання і сенс постановки» (Кузякина, 1984, c. 13). В українському театрі, що тривалий час був позбавлений мовного самовисловлення, й поготів. Тоді ще початківець, Лесь Курбас у 1917 р. писав: «Сучасний український театр - дітище антиукраїнського режиму... Це у кращому разі декілька могікан великої епохи Кропивницького, Тобілевичів і їх перших учнів... У гіршому разі це плоский епігонізм, мізерна копія корифеїв, атмосфера грубо дилетантського ставлення до мистецтва, серед якої жменька самостійних талановитих одиниць ламає своє життя, мимоволі втрачає свою індивідуальність і, зживаючись з традиціями, старіє для всякого почину. I ми зрозуміли, - продовжував Лесь Курбас, - що новий український театр не може ні в якому разі постати зараз. Що він витворюватиметься роками. І коли ніхто за почин не брався, коли нікуди було нам пристати, ми самі казали: може це доля?» (Лабінський, ред., 1991, с.28).

Насправді доленосна роль Леся Курбаса в становленні українського професійного театру виявилася не відразу. Поняття «режисер» виникає в ньому в 1880-ті рр., у період його бурхливого самоствердження, коли режисер ще не був відокремленим від антрепренера, актора та навіть драматурга, й усі вони прагнули художнього поєднання, особливо ж у п'єсах із селянського життя (інша тематика була українському театру заборонена до 1905 р.). «У постановках Кропивницького, Старицького, у роботах Саксаганського проявляються риси власне інтерпретаторського початку, закладаються основи режисерської культури. Проте виникнення спектаклю-концепції (на якому пізніше наполягав Курбас) виявилося ще неможливим завдяки слабкій диференціації обов'язків постановника й драматурга, а також тому, що, виробивши за чверть століття свою естетику, трупи корифеїв передавали її «з вуст у вуста» в прямому значенні цього слова» (Кузякина, 1984, с.8).

У виступах багатьох невеликих труп (а їх усього на початку XX ст. було майже тридцять) переважали штампи «малоросійської вистави» з піснями, танцями та горілкою. Інтерес до такого роду видовищ відчутно зменшувався, українська критика висловлювалася щодо профанації національного мистецтва, спекуляції навколо патріотичної захопленості народним побутом на сцені та про кризу театру. Ось чому, коли в 1907 р. вся українська преса відзначала 25-річчя театру корифеїв, ювілей викликав надзвичайно бурхливу полеміку, пов'язану з оцінкою театру як системи: якщо для одних критиків вона була істинно народною та естетично зразковою, то інші обговорювали однобокість їі ідей та застиглість форм. Корективи в ці процеси внесла драматургічна творчість Лесі Українки, О. Олеся, В. Винниченка, Г. Хоткевича, В. Самійленка та інших. Сучасні п'єси вимагали від режисера не просто організації спектаклю, але підготовки естетичної платформи 
Вісник Київського національного університету культури і мистецтв.

Серія: Сценічне мистецтво

для сценічного втілення неоромантичної, символічної, публіцистичної драми, п'єси-хроніки тощо.

Нові ідеї щодо розвитку сценічного мистецтва висловив актор, поет і перекладач М. Вороний у книзі «Театр і драма» (1913). Як наголошувала Н. Кузякіна: «Це видання разом з брошурою Г. Гаєвського «Завдання режисера. Театральний порадник» (1920) були першими україномовними роботами, що стосувались проблем режисури» (Кузякина, 1984, с.9). Обидві праці та їх автори заслуговують на увагу.

у 1920 р. на допомогу навчальному процесу з театральної справи була започаткована спеціальна серія видань «Театральний порадник», що виходила в Києві упродовж 1920-1923 років. Першою книгою серії стала робота українського режисера й театрального художника Г. Гаєвського (1872-1933) «Завдання режисера». Це, по суті, перший в Україні підручник з режисури. У своїй роботі він висвітлює питання сценічного мистецтва, ролі та завдання режисера й актора в ньому. Тут також досліджено методи та стилі постановок, спільну працю режисера з акторами тощо. У книзі розміщено понад 40 чорно-білих та кольорових малюнків декорацій до вистав, які пояснюють думки автора та дозволяють читачам краще уявити особливості праці режисера.

Г. Гаєвський характеризує театр властивим післяреволюційній добі способом: як рід мистецтва, що виявляється живим словом, найбільш виразним і доступним для зрозуміння масами. Драматичний актор має можливість впливати на слухача безпосередньо; він передає йому з кону певно зрозумілі думки та ідеї авторів при відповідній обстановці, беручи собі в допомогу ще інші роди мистецтва... Досягнення ансамбля можливо лише тоді, коли розрізнені індивідуальні розуміння акторами не тільки всього літературно-артистичного твору в цілому, але навіть і розуміння окремих сцен в п'єсі та ролей будуть зведені до одного загального й спільного для всіх акторів розуміння речі і утворять один повнозвучний і гармонійний акорд.

Так, як найкращі солісти-музики, що беруть участь в оркестрі, потребують диригента, який встановлює загальні для всіх музик-оркестрантів нюанси, темпи та розуміння якоїсь симфонії чи опери, так само і драматичні актори потребують для свого об'єднання певної особи, що міцно їх зтулює і творить артистичний ансамбль, себто дає одну спільну душу, її спільне розуміння тієї праці, до якої взялося багато осіб - до виконання п'єси. Такою особою є режисер (Вороний, 1913, с.30).

Майбутнє українського театру вбачалося М. Вороному не дуже прозорим, проте ще у 1913 р. він казав про прийдешні соціальні катаклізми, в яких «широкі пролетарські маси скажуть своє слово і в мистецтві». У безпосередній зв'язок з цим письменник ставив можливе панування на сцені соціальної драми - вона «дасть цікаві імпульси і відкриє широкі перспективи» (Вороний, 1913, с.28). Якою буде роль режисера за нових умов, з книги М. Вороного було незрозумілим. Проте очевидним поставало завдання побудови нового театру, що вимагало підключення до цього процесу працівників іншого рівня культури: йшлося про різноманітність духовних інтересів, інтелігентність і вільне володіння спадщиною минулого. 
Потрібний був і європейський рівень осягнення театральних ідей, практичне знання досвіду великих режисерів сучасності.

Історичні обставини склалися так, що проблема, конче важлива для центрів Росії, - збереження старих театрів як носіїв культури - в Україні мала інший сенс. Наприклад, театр М. Садовського в 1917-1918 рр. продовжував існувати як приватна антреприза, але процес його творчого занепаду, почавшись ще в 1914-1915 рр., усе посилювався, тож захисників театру було замало. Але з його зникненням питання про традиції театру корифеїв, їх сенс і значення для подальшого розвитку українського мистецтва не знімалося. Воно виявилося важливим і практично (адже переважна маса акторів і глядачів була вихована спектаклями саме цього театру), і теоретично - як оцінка найбільш життєздатного в національній культурі (Кузякина, 1984, с.8).

Природно, найпростішим був шлях прямого збереження форм традиційного театру. Консервувалася мальовничість, музикальність, підкреслена барвистість зображення народного життя. Але зберігалося й безліч штампів, народжених нетворчим повторенням зразків минулого. Тут панувала театральна рутина й не було відкрито жодних перспектив її оновлення. Проблему збереження досягнень старого театру, але на іншому рівні намагався вирішити П. Саксаганський, який зробив спробу відновити зразкові спектаклі театру корифеїв.

Українські драматичні колективи, які формувалися в 1917-1922 рр., тією чи іншою мірою відштовхувалися від заяложених форм традиційного театру. Виникає навіть поняття театру і актора «європейських форм», тобто здатного працювати в європейській класиці. Репертуарну основу нових театрів складала українська та зарубіжна п'єса XX ст. Державний театр, Національний театр, Перший державний театр УРСР ім. Т. Шевченка - це, по суті, була одна й та ж трупа акторів (І. Мар'яненко, М. Тинський, С. Каргальський, Н. Дорошенко та ін.), що проходила в Києві крізь різноманітні трансформації часу. Художніми керівниками, режисерами цих театрів ставали артисти російської школи: О. Загаров, Б. Крживецький, К. Бережний, А. Смирнов та ін.; чимало в них працювало й акторів, що ввібрали в себе досвід російської сцени: Є. Сидоренко, Г. Мещерська, Л. Гаккебуш та ін.

Режисери російської школи зробили в ті роки чимало, готуючи українського актора для роботи над європейською й надалі російською класикою. В українському театрі поняття культури слова, тексту не набуло тоді першочергової ваги. Очевидно, що найбільш плідним був шлях формування нової режисури в самому процесі розвитку українського театру, який повинен увібрати в себе сучасні ідеї та форми, але переробити їх відповідно до своїх внутрішніх потреб.

До середини 20-х рр. в українському сценічному мистецтві в процесі природного художнього розмежування визначилися дві системи: одна з них тяжіла до форм театру прямих життєвих відповідностей (найяскравіше втілювалася в діяльності Г. Юри), інша на чолі з Лесем Курбасом виступала під прапором «лівого» мистецтва, стверджувала на сцені умовні форми. Обоє були закономірними, хоча перша мала видиму опору в традиціях театру корифеїв, а другій необхідно було зміцнити естетичний ґрунт для подальшого розвитку. 
Вісник Київського національного університету культури і мистецтв.

Серія: Сценічне мистецтво

Сценічним умовностям театру прямих життєвих відповідностей Лесь Курбас протиставив іншу систему умовностей, назвавши її системою «образного перетворення», тобто художніх видозмін реальності в мистецтві. Не мистецтво у формах життя, а життя у формах мистецтва - так він сформулював свою режисерську тезу, хоча її практичне втілення бувало різним.

Наукова новизна дослідження полягає в тому, що звернення до призабутих естетичних концепцій минулого дало змогу з нових позицій подивитися на усталені уявлення минулих часів і відповідно надати їм сучасного наукового трактування.

Висновки. 3 початку 1970-х протягом майже 20 років в Ленінградському державному інституті театру, музики та кінематографії працювала як викладач і науковець українського походження Н. Кузякіна, якій не знайшлося місця в рідному науковому середовищі. Саме їй довелося зіграти чималу роль у знайомстві наукової громадськості та студентів театральних спеціальностей з неупередженою оцінкою української театральної культури. У посібнику, який випустила дослідниця 1984 р., відображено складні процеси становлення української режисури та заслуги його визначного майстра Леся Курбаса, який у 1917 р. писав, що сучасний український театр - дітище антиукраїнського режиму та не чекав у найближчі часи того, що має витворюватися роками.

Насправді доленосна роль Леся Курбаса в становленні українського професійного театру виявилася не відразу. Уже в 1917-1918 рр. у Києві з'явилися перші театри, в яких реалізувалося бажання знайти нові шляхи для українського мистецтва. У їхній практиці, в узагальненні її на сторінках газет і журналів виразився й процес формування нової режисури. Г. Гаєвський розрізняв завдання режисерської професії у двох напрямах - способах виявлення ідей автора на сцені: режисер задуму та режисер виконання. Режисер, на думку Г. Гаєвського, мав виявити дар колективної уяви та перш за все вміти бачити перед собою цілу п'єсу, як її треба показати глядачам, а потім уже забезпечити майстерне виконання ролей окремими особами, що беруть участь у втіленні вистави на сцені.

Посилаючись на досвід європейського та російського театру, зокрема на вистави МХТ, М. Вороний стверджував, що ідея драми оформлюється на сцені за допомогою так званої «режисерської» або «драматичної» перспективи. Насправді така «перспектива» Вороного була зародком концепції вистави, хоча й пов'язана для автора тільки з постановками психологічної та неоромантичної драми.

Молодий театр, створений Лесем Курбасом в 1917 р., став тією необхідною школою професійного навчання, яку проходили актори та майбутні режисери (Г. Юра, М. Терещенко, В. Василько та ін.). Потім їх шляхи розійшлися, але у створених ними колективах (Г. Юрою - театру ім. І. Франка, Лесем Курбасом - «Кийдрамте», «Березіль», М. Терещенком - театру ім. Г. Михайличенка) продовжувався процес опрацювання нової естетичної мови.

Система умовних форм у спектаклях Леся Курбаса уможливила нові прийоми втілення прози та поезії на сцені українського театру, створення політичної вистави як принципово нового явища й випробування інших театральних форм. У режисерській лабораторії «Березіля» отримали професійну освіту багато українських режисерів 1920-40-х рр. 
Цими обставинами Н. Кузякіна пояснювала необхідність розмови про українську режисуру тих років, осягнути масштаби творчої особистості Леся Курбаса та сукупність його починань, що принципово змінили вигляд українського театру.

Перспективи подальших досліджень вбачаємо в розширенні наукового кола досліджуваних явищ, що б уможливило їх неупереджений розгляд. Йдеться не тільки про мистецтвознавчу оцінку результатів творчості Леся Курбаса та його сучасників, а й про безпосередні глядацькі враження людей, жодним чином не підготовлених до кардинальних новацій у мистецтві театру.

\section{СПИСОК ПОСИЛАНЬ}

Волицька, І., 2008. Уроки Наталі Кузякіної. Слово і Час, 12. с.33-39.

Вороний, М., 1913. Театр і драма. Київ: Волосожар.

Гаєвський, Г., 1930. Завдання режисера. Театральний порадник, 1. Київ: Дніпросоюз.

Кузякина, Н.Б., 1984. Становление украинской советской режиссуры (1920-начало 30-хг.) Ленинград:Ленинградский государственный институт театра, музыки и кинематографии. Лабінський, М.Г. ред., 1991. Молодий театр : генеза, завдання, шляхи : [статті, спогади, матеріали]. Київ: Мистецтво, Спілка театральних діячів України.

Рудницький, К. ред., 1966. История советского драматического театра. В: 6-т. Т. 1: 1917-1920. Москва: Наука.

Рудницький, К. ред., 1966. История советского драматического театра. В: 6-т. Т. 2: 1921-1925. Москва: Наука.

Строева, М.Н. ред., 1967. История советского драматического театра. В: 6-т. Т. 3: 1926-1932. Москва: Наука.

Хваленская, Е. ред., 1976. У истоков режиссуры. Очерки из истории русской режиссуры конца XX-начала XXI века. Ленинград: Ленинградский государственный институт театра, музыки и кинематографии.

\section{REFERENCES}

Volytska, I., 2008. Uroky Natali Kuziakinoi [Lessons of Natali Kuziakino]. Slovo i Chas, 12. pp.33-39. Voronyi, M., 1913. Teatr i drama [Theater and Drama]. Kyiv: Volosozhar.

Haievskyi, H., 1930. Zavdannia rezhysera [The director's performance]. Teatralnyi poradnyk, 1. Kyiv: Dniprosoiuz.

Kuziakina, N.B., 1984. Stanovlenie ukrainskoi sovetskoi rezhissury (1920-nachalo 30-kh rokiv) [Formation of Ukrainian Soviet direction (1920-early 30s)] Leningrad: Leningrad State Institute of Theater, Music and Cinematography.

Labinskyi, M.H. ed., 1991. Molodyi teatr : heneza, zavdannia, shliakhy : [statti, spohady, materialy] [Young theater: genesis, problem, paths: [articles, memoirs, materials]]. Kyiv: Mystetstvo, Spilka teatralnykh diiachiv Ukrainy.

Rudnitckii, K. ed., 1966. Istoriia sovetskogo dramaticheskogo teatra [History of the Soviet Drama Theater]. In: 1-6 Vols. Vol. 1: 1917-1920. Moscow: Nauka.

Rudnitckii, K. ed., 1966. Istoriia sovetskogo dramaticheskogo teatra [History of the Soviet Drama Theater]. In: 1-6 Vols. Vol. 2: 1921-1925. Moscow: Nauka.

Stroeva, M.N. ed., 1967. Istoriia sovetskogo dramaticheskogo teatra [History of the Soviet Drama Theater]. In: 1-6 Vols. Vol. 3: 1926-1932. Moscow: Nauka. 
Khvalenskaia, E. ed., 1976. U istokov rezhissury. Ocherki iz istorii russkoi rezhissury kontca $X X$-nachala XXI veka [At the origins of directing. Essays from the history of Russian directing the end XX-beginning of the XXI century]. Leningrad: Leningrad State Institute of Theater, Music and Cinematography.

\section{ИСТОКИ ИСКУССТВА РЕЖИССУРЫ. ИЗ ПРИЗАБЫТЫХ РАБОТ УКРАИНСКИХ ТЕАТРОВЕДОВ}

\section{Александр Чепалов}

доктор искусствоведения, профессор; e-mail: chepalovst@gmail.com; ORCID: 0000-0002-2033-357X Киевский национальный университет культуры и искусств, Киев, Украина

\section{Аннотация}

Режиссура как творческая профессия и проблема создания авторского театрального спектакля остается уже более века в центре обсуждения театроведов, культурологов и специалистов других отраслей, близких к сценическому искусству. Целью данного исследования является возвращение в круг обсуждаемых проблем современного театра подзабытых в настоящее время работ искусствоведческого профиля, которые характерны для ключевых моментов истории Украины: идейно-политического самоопределения после 1917 г. (М. Вороной, Г. Гаевский) и возвращения к общественной памяти творческих достижений выдающегося украинского режиссера Леся Курбаса (Н. Кузякина, последняя четверть XX ст.). Методы исследования (в первую очередь исторический) обусловлены существенными временными промежутками, к которым мы ретроспективно возвращаемся, учитывая значимость того или иного художественного события, его политическую заангажированность и тому подобное. Другим преобладающим методом выступает в работе сравнительный, который демонстрирует сходство или отличие художественных приемов театрального спектакля в связи с разными общественно-политическими или идеологическими требованиями. Сравнительный метод делает возможным анализ признаков художественного явления с целью их классификации и типологической структуризации. Научная новизна исследования заключается в том, что обращение к подзабытым эстетическим концепциям прошлого (Г. Гаевский, М. Вороной) дает возможность по-новому посмотреть на устоявшиеся представления прошедших времен и соответственно представить их в современной научной трактовке. Выводы исследования касаются в первую очередь места и роли Леся Курбаса в разнообразных проявлениях европейской режиссерской теории и практики XX ст., что до сих пор недостаточно оценено вне пределов украинской театральной культуры.

Ключевые слова: режиссура; украинское режиссерское искусство; театроведческие аспекты режиссуры; Н. Кузякина; театр корифеев; система «образного перевоплощения» Леся Курбаса 


\title{
ORIGINS OF ART DIRECTOR. FROM THE PREVIOUS WORKS OF UKRAINIAN THEATRICS
}

\section{Oleksandr Chepalov}

Doctor of Art History, professor; e-mail: chepalovst@gmail.com; ORCID: 0000-0002-2033-357X Kyiv National University of Culture and Arts, Kyiv, Ukraine

\begin{abstract}
Direction as a creative profession and the problem of creating an author's theatrical performance has been over the century in the center of discussion of theatrical scholars, cultural experts and specialists of other branches, touching the stage art. The purpose of the article is to include in the scope of the contemporary theoretical problems the forgotten works of the art history profile which were characteristic of the key moments of Ukrainian history: ideological and political self-determination after 1917 (M. Voronyi, G. Gaevsky) and returning to the public memory of creative the achievements of the outstanding Ukrainian director Les Kurbas (N. Kuzyakin, the last quarter of the twentieth century). Research methods of (primarily historical) are due to significant time intervals, to which we retrospectively return, given the significance of a particular artistic event, its political engagement, etc. Another dominant method is comparative, that is, one that demonstrates the similarity or difference between artistic techniques of theatrical performance in connection with a certain socio-political or ideological requirements. The comparative method makes it possible to analyze the features of the artistic phenomenon for the purpose of their classification and typological structuring. The scientific novelty of the work consists in the fact that the appeal to forgotten aesthetic concepts of the past (G. Gaevsky, M. Voronyi) gave an opportunity to look in a new way on the established representations of the past times and, accordingly, provide them with modern scientific interpretation. The findings of the study primarily relate to the place and role of Les Kurbas in various manifestations of European directorial theory and practice of the twentieth century, which are still not sufficiently appreciated outside the Ukrainian theatrical culture.
\end{abstract}

Keywords: directing; Ukrainian directing art; theatrical aspects of directing; N. Kuzyakina; coryphaeus theater; the system of "figurative transformation" by Les Kurbas 